\title{
PENGARUH KOMPETENSI DAN MOTIVASI TERHADAP KINERJA KARYAWAN PT ANTAM TBK UBPP LOGAM MULIA
}

\author{
Dwi Paryanti ${ }^{1)}$ \\ 1) Mahasiswa Program Studi Manajemen FE UNKRIS \\ Rasmansyah ${ }^{2)}$ \\ 2) Dosen Program Studi Manajemen FE UNKRIS \\ Alamat: Kampus UNKRIS, Jatiwaringin Jakarta Timur \\ Email : rasmansyah31@gmail.com
}

\begin{abstract}
This study aims to determine the role of competence and motivation in improving the performance of employees of PT. Antam Tbk UBPP Logam Mulia. The sample taken in this study were all employees, amounting to 102 people. Based on the results of hypothesis testing shows that competence and motivation have a positive and significant effect on employee performance at PT. Antam Tbk UBPP Logam Mulia.
\end{abstract}

\section{Keywords: Competence, motivation and employee performance}

\section{PENDAHULUAN}

Peranan sumber daya manusia dinilai sangat penting dalam setiap kegiatan perusahaan. sumber daya manusia dalam suatu perusahaan berfungsi sebagai pelaksana dalam menjalankan aktivitas perusahaan. Potensi dari sumber daya manusia yang ada harus dimanfaatkan dengan sebaik-baiknya agar memperoleh hasil yang maksimal, serta bagaimanapun juga kemajuan dan keberhasilan dari suatu perusahaan juga tidak lepas dari peran sumber daya manusia yang baik di dalam nya. Peningkatan kinerja dapat diwujudkan melalui adanya penyesuaian, seperti peningkatan kompetensi dan motivasi. Sehingga setiap karyawan dapat berkontribusi langsung dalam kepentingan perusahaan. Kompetensi yang tinggi yang dimiliki oleh sumber daya manusia dan dorongan motivasi yang kuat dalam suatu organisasi tentu akan menentukan kualitas sumber daya manusia yang dimiliki dan pada akhirnya akan menentukan kualitas kompetitif perusahaan.

Motivasi kerja merupakan kebutuhan pokok manusia dan sebagai insentif yang diharapkan memenuhi kebutuhan pokok yang diinginkan, sehingga jika kebutuhan itu ada akan berakibat pada kesuksesan terhadap suatu pekerjaan. Karyawan yang mempunyai motivasi kerja tinggi akan berusaha agar pekerjaannya dapat terselesaikan dengan sebaikbaiknya. Kuat lemahnya motivasi kerja seorang tenaga kerja ikut menentukan besar kecilnya kinerja.

Menurut Busro (2018) bahwa kinerja menunjukan kemampuan dan keterampilan pekerja. Pendapat ini lebih menekankan kompetensi sumber daya manusia yang dimiliki oleh organisasi, mulai dari kemampuan kognisi, afeksi, dan psikomotor karyawan. Dengan kata lain, kinerja disini lebih mengarah pada hasil dari kemampuan dan keterampilan yang dimiliki oleh pekerja.

Berikut tabel grafik kompetensi, motivasi dan kinerja karyawan PT. Antam tbk, UBPP Logam Mulia. Terlihat dalam periode tersebut terdapat peningkatan kompetensi yang tentunya guna menunjang perbaikan kinerja karyawan PT. Antam Tbk UBPP Logam Mulia. Berikut ini tabel kinerja karyawan PT. Antam Tbk UBPP Logam Mulia tahun 2016-2018. 
Tabel 1: Kinerja Karyawan PT. Antam Tbk, UBPP Logam Mulia

\begin{tabular}{|c|c|c|c|c|c|}
\hline \multirow{2}{*}{ No } & \multirow{2}{*}{ Variabel } & \multirow{2}{*}{$\begin{array}{c}\text { Target } \\
(\%)\end{array}$} & \multicolumn{3}{|c|}{ Realisasi (\%) } \\
\hline & & & 2016 & 2017 & 2018 \\
\hline 1 & Kompetensi & 100 & 31 & 34 & 35 \\
\hline 2 & Motivasi & 100 & 29 & 30 & 28 \\
\hline 3 & Kinerja & 100 & 28 & 29 & 26 \\
\hline \multicolumn{3}{|c|}{ Total } & 88 & 93 & 89 \\
\hline
\end{tabular}

Sumber: PT Antam Tbk, UBPP Logam Mulia, 2019

Dari Tabel 1, dapat dilihat bahwa motivasi karyawan cenderung terjadi penurunan, hal ini perlu dilakukan analisis lebih lanjut, sedangkan kinerja karyawan belum terealisasi dengan sempurna. Hal ini menjadi indikasi bahwa dari tahun 2016-2018 telah terjadi penurunan kinerja karyawan PT. Antam Tbk. UBPP Logam Mulia. Dengan adanya data ini menjadi indikasi terdapatnya masalah pada kinerja karyawan, sehingga perlu dikaji secara empiris mengenai peranan kompetensi dan motivasi terhadap kinerja karyawan PT. Antam Tbk. UBPP Logam Mulia. Tujuan penelitian ini adalah untuk menganalisis pengaruh kompetensi dan motivasi terhadap kinerja karyawan PT. Antam Tbk. UBPP Logam Mulia

\section{LANDASAN TEORI}

\section{Kompetensi}

Menurut Busro (2018), kompetensi adalah bagian kepribadian yang mendalam dan melekat pada seseorang dengan perilaku yang dapat diprediksi pada berbagai keadaan dan tugas pekerjaan. Selanjunta menurut Piandi (2018), kompetensi adalah perpaduan dari pengetahuan, keterampilan, nilai dan sikap yang direfleksikan dalam kebiasaan berfikir dan bertindak. Pengertian kompetensi menurut Undang-undang No. 13 Tahun 2003 Pasal 1(10) tentang ketenagakerjaan adalah kemampuan kerja setiap individu yang mencakup aspek pengetahuan, keterampilan, dan sikap kerja yang sesuai dengan standar yang ditetapkan. Kompetensi yang umum dikemukakan adalah pengambilan keputusan, pengambilan resiko, pengembangan relasi, pemecahan masalah, analisis, perhatian terhadap detail, inovasi, kelenturan, layanan pelanggan, perspektif strategik, kerjasama tim, dan kepemimpinan. Jadi dapat disimpulkan bahwa kompetensi adalah seperangkat perilaku kinerja individu yang dapat diamati, terukur dan sangat penting untuk keberhasilan kinerja pada individu itu sendiri maupun pada perusahaannya. Perilaku kinerja individu tersebut meliputi pengetahuan, keterampilan, kemampuan dan karakteristik yang terkait dengan aspek kinerja praktik profesi.

Menurut Spencer dan Spencer yang dikutip oleh Kompri (2017), indikator kompetensi adalah: 1). Motif (motive); dorongan kebutuhan ekonomi, dorongan kebutuhan sosial dan dorongan kebutuhan psikologis. 2). Watak (traits); watak, sifat dan sikap. 3). Konsep diri (self-concept); penampilan, tutur bahasa dan perilaku. 4). Pengetahuan (knowledge); pengetahuan tentang prosedur dan pengetahuan tentang teknis. 5). Keterampilan (skill); keterampilan administratif, keterampilan manajerial, keterampilan teknis dan keterampilan sosial.

\section{Motivasi}

Pamela dan Oloko (2015), motivasi adalah kunci dari organisasi yang sukses untuk menjaga kelangsungan pekerjaan dalam organisasi dengan cara dan bantuan yang kuat untuk bertahan hidup, sedangkan Shaleh (2018) mengungkapkan bahwa motivasi 
merupakan hasrat di dalam diri seseorang yang menyebabkan orang tersebut melakukan tindakan. Karyawan yang memiliki motivasi tinggi cenderung melakukan pekerjaan dengan sungguh-sungguh dan berusaha meningkatkan kemampuan dalam menyelesaikan pekerjaan. Dari pengertian motivasi tersebut dapat disimpulkan bahwa motivasi merupakan dorongan terhadap serangkaian proses perilaku manusia pada pencapaian tujuan, sedangkan elemen yang terkandung dalam motivasi meliputi unsur membangkitkan, mengarahkan, menjaga, menunjukkan instensitas, bersifat terus menerus dan adanya tujuan.

Beberapa teori motivasi yang pada umumnya dikenal dan dikemukakan oleh para ilmuwan yang menekuni kegiatan pengembangan teori motivasi. Menurut Priansa (2014) beberapa teori motivasi tersebut antara lain: 1). Teori Maslow; Teori motivasi yang paling terkenal adalah hierarki teori kebutuhan milik Abraham Maslow, ia membuat hipotesis bahwa dalam setiap diri manusia terdapat hierarki dari lima kebutuhan, yaitu: a). fisiologis (rasa lapar, haus, seksual, dan kebutuhan fisik lainnya), b). rasa aman (rasa ingin dilindungi dari bahaya fisik dan emosional), c). sosial (rasa kasih sayang, kepemilikan, penerimaan, dan persahabatan), d). penghargaan (faktor penghargaan internal dan ekternal), dan e). aktualisasi diri (pertumbuhan, pencapaian potensi seseorang, dan pemenuhan diri sendiri). 2). Teori motivasi berprestasi McClelland; Ada tiga kebutuhan manusia yang menonjol, yaitu: a). Need of achievement (kebutuhan untuk berprestasi), b). Need of affiliation (kebutuhan untuk memperluas pergaulan), dan c). Need of power (kebutuhan untuk menguasai sesuatu). 3). Teori ERG dari Clayton Alderfer; Teori ERG, dalam teorinya setuju dengan Maslow bahwa kebutuhan-kebutuhan individual tersusun secara hierarki, namun demikian hierarki kebutuhan yang diusulkan hanya terdiri dari tiga set kebutuhan, yaitu: a). Eksistensi (existence), yaitu makanan, kebutuhan akan udara, air gaji, dan kondisi pekerjaan. b). Keterkaitan (relatedness), yaitu kebutuhan akan kebutuhan sosial dan interpersonal yang berarti. c). Pertumbuhan (growth), yaitu kebutuhan seseorang individu untuk menciptakan kontribusi yang kreatif atau produktif. 4). Teori dua faktor Herzberg; Teori ini dikembangkan oleh Frederic Herzberg, teori ini juga menggunakan teori Maslow sebagai titik acuan nya. Teori Herzberg dapat dikategorikan dalam dua faktor, menurut Busro (2018) yaitu: 1). Faktor motivator;

Faktor motivator ini dapat memacu seseorang untuk bekerja lebih baik dan bergairah. Faktor yang ada dalam rangkaian ini disebut satisfier atau motivator yang meliputi : a). Pencapaian; b). Pengakuan; c). Tanggung jawab; d). Kemajuan; e). Pekerjaan itu sendiri; f). Kemungkinan untuk tumbuh. 2). Faktor hygiene; Keberadaan faktor ini tidak akan meningkatkan motivasi kerja, namun jika faktor ini tidak ada akan menimbulkan ketidakpuasan. Kondisi ini adalah dissatisfier atau faktor hygiene, karena faktor tersebut untuk mempertahankan suatu tingkat dari adanya kepuasan, antara lain: a). Gaji; b). Keamanan pekerjaan; c). Kondisi kerja; d). Status; e). Prosedur perusahaan; f). Kualitas pengamanan teknis, dan g). Kualitas hubungan interpersonal. Indikator motivasi kerja menurut Wibowo (2011) adalah: 1). Kebutuhan untuk berprestasi. 2). Kebutuhan memperluas pergaulan. 3). Kebutuhan untuk menguasai sesuatu pekerjaan

\section{Kinerja}

Menurut Rismawati dan Mattalata (2018), kinerja adalah hasil kerja secara kualitas dan kuantitas yang dicapai oleh seseorang karyawan dalam melaksanakan tugas nya sesuai dengan tanggung jawab yang diberikan kepadanya. Sinambela (2018), kinerja merupakan suatu fungsi dari motivasi dan kemampuan. Untuk menyelesaikan tugas dan pekerjaan, seseorang harus memiliki derajat kesediaan dan tingkat kemampuan tertentu. 
Kesediaan dan keterampilan tidaklah cukup efektif untuk mengerjakan sesuatu tanpa pemahaman yang jelas tentang apa yang akan dikerjakan dan bagaimana mengerjakannya.

Berdasarkan pendapat beberapa pakar dapat disimpulkan bahwa kinerja merupakan suatu kondisi yang harus diketahui dan dikonfimasikan kepada pihak tertentu untuk mengetahui tingkat pencapaian hasil suatu instansi dihubungkan dengan visi yang diemban suatu perusahaan atau perusahaan serta mengetahui dampak positif dan negatif dari suatu kebijakan operasional. Menurut Bangun (2012), tujuan dan manfaat penilaian kinerja diantaranya adalah: 1). Evaluasi antar individu dalam organisasi. Penilaian kinerja dapat bertujuan untuk menilai kinerja setiap individu dalam organisasi tujuan ini dapat memberi manfaat dalam menentukan jumlah dan jenis kompensasi yang merupakan hak bagi setiap individu dalam organisasi. 2). Pengembangan diri setiap individu dalam organisasi. Penilaian kinerja dalam organisasi ini bermanfaat untuk pengembangan karyawan. Setiap individu dalam organisasi dinilai kinerjanya, bagi karyawan yang memiliki kinerja rendah perlu dilakukan pengembangan baik melalui pendidikan maupun pelatihan. 3). Pemeliharaan system. Berbagai sistem yang ada dalam organisasi, setiap subsistem yang ada saling berkaitan antara satu subsistem lainya. Salah satu subsistem yang tidak berfungsi dengan baik akan menggangu jalannnya subsistem yang lain. Oleh karena itu, sistem dalam organisasi perlu dipelihara dengan baik. 4). Dokumentasi penilaian kinerja akan memberi manfaat sebagai dasar tindak lanjut dalam posisi pekerjaan karyawan di masa yang akan datang. Manfaat penilaian kinerja disini berkaitan dengan keputusan-keputusan manajemen sumber daya manusia, pemenuhan secara legal manajemen sumber daya manusia, dan sebagai kriteria untuk pengujian validitas.

Parastika (2016) menjelaskan terdapat delapan indikator pengukuran kinerja menurut teori Dessler yaitu: 1). Pemahaman Pekerjaan/Kompetensi. 2). Kualitas/Kuantitas Kerja. 3). Perencanaan/Organisasi. 4). Inisiatif/Komitmen. 5). Penyelesaian masalah atau kreativitas. 6). Kerja Tim dan Kerja Sama. 7). Kemampuan berhubungan dengan orang lain. 8). Komunikasi (lisan dan tulisan)

\section{METODE PENELITIAN}

Penelitian ini untuk menjelaskan hubungan kausalitas variabel kompetensi dan motivasi. Data yang digunakan dalam penelitian ini merupakan data primer melalui pengisian kuesioner kepada karyawan PT. Antam Tbk, UBPP Logam Mulia. Metode analisis yang digunakan adalah metode analisis regresi linear sederhana dan berganda. Populasi dalam penelitian ini adalah karyawan kontrak pada beberapa divisi di PT. Antam Tbk, UBPP Logam Mulia yang berjumlah 102 karyawan. Penentuan jumlah sampel yang digunakan dalam penelitian ini yaitu sampel jenuh (sensus). Semua anggota populasi digunakan sebagai sampel.

\section{HASIL PENELITIAN DAN PEMBAHASAN}

\section{Hasil Penelitian}

\section{Hasil uji validitas dan uji reliabilitas}

Untuk dapat menentukan variabel kompetensi dan motivasi dapat dijadikan pengukur terhadap kinerja karyawan PT. Antam Tbk, UBPP Logam Mulia. Namun sebelumnya data diolah terlebih dahulu dan dilakukan pengujian terhadap varibel yang digunakan yaitu 
kompetensi, motivasi dan kinerja untuk mengetahui apakah data tersebut akurat dan dapat dipercaya.

Pengujian validitas ini dilakukan untuk menguji apakah tiap butir pernyataan telah mewakili indikator yang akan diteliti, persyaratan minimum untuk dapat dikatakan valid adalah $\mathrm{r}=0,30$. Jadi, apabila korelasi antara butir-butir pernyataan dengan skor total kurang dari 0,30, maka butiran dalam instrumen tersebut dapat dikatakan tidak valid. Uji validitas dilakukan dengan melihat korelasi antara skor masing-masing butir pernyataan dengan skor total. Dari 102 responden, butir pernyataan kompetensi berjumlah 5 pernyataan, motivasi sebanyak 3 pernyataan, dan kinerja karyawan sebanyak 8 pernyataan. Berdasarkan perhitungan koefisien korelasi skor tiap butir pernyataan menunjukkan bahwa semua butir pernyataan variabel kompetensi, motivasi dan kinerja karyawan hasilnya adalah valid (r-hitung $>$ r-tabel).

Pengujian reliabilitas ini dilakukan untuk menguji seberapa jauh hasil pengukuran yang dapat diandalkan secara konsisten. Berdasarkan tabel 2, hasil pengujian reliabilitas berikut, diketahui bahwa semua variabel mempunyai alpha di atas 0.7 yang berarti bahwa semua variabel dalam penelitian ini dapat diandalkan. Berdasarkan tabel 2, dapat diketahui bahwa nilai Cronbach's Alpha untuk ketiga variabel yang diteliti adalah 0,7. Karena nilainilai ukur tersebut lebih besar dari 0,7 maka nilai ukur tersebut realiabel atau telah memenuhi syarat realibilitas.

Tabel 2: Hasil Uji Reliabilitas Variabel

\begin{tabular}{lcc}
\hline \multicolumn{1}{c}{ Variabel } & Cronbach's Alpha & Keterangan \\
\hline Kompetensi & 0.789 & Reliabel \\
Motivasi & 0.791 & Reliabel \\
Kinerja Karyawan & 0.834 & Reliabel \\
\hline
\end{tabular}

Sumber: Hasil pengolahan data, 2019

\section{Analisis regresi linear sederhana}

Tabel 3: Pengaruh Kompetensi terhadap Kinerja Karyawan

\begin{tabular}{lcccc}
\hline \multirow{2}{*}{ Variabel } & \multicolumn{4}{c}{ Parameter } \\
\cline { 2 - 5 } & Konstanta & Koef. Regresi & Sig. & $\boldsymbol{\alpha}$ \\
\hline Kompetensi & 6.496 & 0.597 & 0.000 & 0.05 \\
\hline $\mathrm{t}$ hitung $>\mathrm{t}$ tabel $=5.546>1.984$ \\
$\mathrm{R}^{2}$ & 0, & & \\
\hline
\end{tabular}

Keterangan : Variabel kinerja karyawan

Sumber: data diolah 2019

Berdasarkan tabel 3, persamaan regresi linear sederhana adalah $\mathrm{Y}=6,496+0,597$ $\mathrm{X}_{1}$. Koefisien regresi kompetensi berpengaruh positif dan signifikan terhadap kinerja karyawan PT. Antam Tbk, UBPP Logam Mulia. Koefisien regresi kompetensi bertanda positif, hal ini berarti bahwa jika ada peningkatan kompetensi, maka kinerja karyawan PT. Antam Tbk, UBPP Logam Mulia akan meningkat. 
Tabel 4: Pengaruh Motivasi Terhadap Kinerja Karyawan

\begin{tabular}{lcccc}
\hline \multirow{2}{*}{ Variabel } & \multicolumn{4}{c}{ Parameter } \\
\cline { 2 - 5 } & Konstanta & Koef. Regresi & Sig. & $\boldsymbol{\alpha}$ \\
\hline Motivasi & 6.707 & 5.047 & 0.000 & 0.05 \\
\hline $\mathrm{t}$ hitung $>\mathrm{t}$ tabel $=$ & $6.780>1.984$ & & & \\
\hline $\mathrm{R}^{2}$ & 0, & & \\
\hline
\end{tabular}

Keterangan : Variabel kinerja karyawan

Sumber: data diolah 2019

Berdasarkan tabel 4, persamaan regresi linear sederhana, yaitu $\mathrm{Y}=6,707+5,047 \mathrm{X}_{2}$. Koefisien regresi motivasi berpengaruh positif dan signifikan terhadap kinerja karyawan PT. Antam Tbk, UBPP Logam Mulia. Koefisien regresi motivasi bertanda positif, hal ini berarti bahwa jika ada peningkatan motivasi, maka kinerja karyawan PT. Antam Tbk, UBPP Logam Mulia akan meningkat.

Analisis regresi linear berganda

Tabel 5: Pengaruh Kompetensi dan Motivasi terhadap Kinerja Karyawan

\begin{tabular}{lccccc}
\hline \multirow{2}{*}{ Variabel } & \multicolumn{5}{c}{ Parameter } \\
\cline { 2 - 6 } & R Square & Konstanta & Koef. Regresi & Sig. & A \\
\hline Kompetensi & 0.567 & 5.496 & 0.397 & 0.000 & 0.05 \\
Motivasi & & & 0.440 & 0.05 \\
\hline
\end{tabular}

F-hitung $=6.780>$ F-tabel $=1.984$

Keterangan : Variabel kinerja karyawan

Sumber: data diolah 2019

Berdasarkan tabel 5, pengujian simultan kompetensi dan motiavasi terhadap kinerja karyawan PT. Antam Tbk, UBPP Logam Mulia signifikan atau tidak, dilakukan pengujian F-hitung dibandingkan dengan F-tabel. Nilai F-hitung sebesar 63,446 lebih besar dibandingkan dengan F-tabel sebesar 3,080, dapat diartikan bahwa kompetensi dan motivasi secara bersama-sama berpengaruh signifikan terhadap kinerja karyawan PT. Antam Tbk, UBPP Logam Mulia. Nilai koefisien determinasi $\left(\mathrm{R}^{2}\right)$ sebesar 0,567 yang artinya sumbangan yang diberikan kompetensi dan motivasi kepada kinerja karyawan PT. Antam Tbk, UBPP Logam Mulia sebesar 56,7\%, sedangkan sisanya 43,3\% dipengaruhi oleh faktor lain yang tidak dibahas dalam penelitian ini.

Persamaan regresi linear berganda yaitu $\mathrm{Y}=5,496+0,397\left(\mathrm{X}_{1}\right)+0,440\left(\mathrm{X}_{2}\right)$. Koefisien regresi kompetensi dan motivasi berpengaruh positif dan signifikan terhadap kinerja karyawan PT. Antam Tbk, UBPP Logam Mulia. Koefisien regresi kompetensi bertanda positif, hal ini berarti bahwa jika ada peningkatan kompetensi, maka kinerja karyawan PT. Antam Tbk, UBPP Logam Mulia akan meningkat dengan asumsi motivasi konstan. Koefisien regresi motivasi bertanda positif, hal ini berarti bahwa jika ada peningkatan motivasi, maka kinerja karyawan PT. Antam Tbk, UBPP Logam Mulia akan meningkat dengan asumsi kompetensi konstan.

\section{Pembahasan}

\section{Pengaruh kompetensi terhadap kinerja karyawan}

Berdasarkan hasil penelitian dan pembahasan, ditemukan bahwa kompetensi mendukung peningkatan kinerja karyawan PT. Antam Tbk UBPP Logam Mulia, yang artinya jika kompetensi karyawan semakin baik, maka semakin meningkat pula kinerja 
karyawan. Hal ini dikarenakan oleh perusahaan memberikan kesempatan bagi karyawan untuk pengebangan potensi yang dimiliki, karyawan dalam bekerja mematuhi aturan dan norma yang berlaku, bekerja sesuai dengan standar mutu yang ditetapkan dan pengalaman praktis dan sertifikasi yang dimiliki karyawan sangat membantu dalam bekerja. Hasil penelitian ini mendukung hasil penelitian yang dilakukan oleh Dwiyanti, Ni Kadek Ayu et al, 2019 dan Yuningsih dan Ardianti. 2019, bahwa kompetensi berpengaruh terhadap kinerja karyawan.

\section{Pengaruh motivasi terhadap kinerja karyawan}

Berdasarkan hasil penelitian dan pembahasan, ditemukan bahwa motivasi mendukung peningkatan kinerja karyawan PT. Antam Tbk UBPP Logam Mulia, yang artinya jika motivasi karyawan semakin baik, maka semakin tinggi pula kinerja karyawan. Hal ini dikarenakan oleh perusahaan memberikan kesempatan pada karyawannya untuk selalu mengikuti pelatihan demi pengembangan dirinya, kondisi perusahaan yang baik membuat semangat kerja yang baik antar sesame karyawan dan atasan selalu memberikan motivasi kepada seluruh karyawan untuk bekerja dengan baik. Hasil penelitian ini mendukung hasil penelitian yang dilakukan oleh Hermawan dan Ainah. 2016 dan Kurniasari. 2018. Bahwa motivasi dapat memberikan peningkatan kinerja pegawai.

\section{Pengaruh kompetensi dan motivasi terhadap kinerja karyawan}

Berdasarkan hasil penelitian dan pembahasan, diketahui bahwa kompetensi dan motivasi dapat memberikan dorongan dalam peningkatan kinerja karyawan PT. Antam Tbk, UBPP Logam Mulia, yang artinya jika kompetensi karyawan semakin meningkat dan motivasi karyawan semakin baik, maka semakin tinggi pula kinerja karyawan PT. Antam Tbk. UBPP Logam Mulia. Hasil penelitian ini sesuai dengan kajian empirik dari Pradana, et al (2016) ada pengaruh kompetensi dan motivasi kerja terhadap kinerja karyawan pada Unit Penyelenggara Pelabuhan (UPP) Kelas III Buleleng. Hasil penelitian ini mendukung teori yang dikemukakan oleh Gibson, Ivancevich dan Donnely dalam W Prastika (2016) bahwa faktor yang mempengaruhi kinerja adalah variabel individu yang meliputi kemampuan dan keterampilan (kompetensi) dan variabel psikologis yang meliputi motivasi. Kajian empirik yang turut mendukung temuan penelitian ini adalah hasil penelitian yang dilakukan oleh Suprapto (2009) bahwa kompetensi dan motivasi kerja berpengaruh positif dan signifikan terhadap kinerja karyawan.

\section{KESIMPULAN DAN SARAN}

\section{Kesimpulan}

Berdasarkan hasil penelitian, dapat disimpulkan bahwa kompetensi dan motivasi dapat mendukung peningkatan kinerja karyawan PT. Antam Tbk UBPP Logam Mulia baik secara parsial maupun secara bersama-sama.

\section{Saran}

Berdasarkan kesimpulan hasil penelitian, dapat disampaikan beberapa saran yang kiranya bermanfaat bagi peningkatan kinerja karyawan PT. Antam Tbk. UBPP Logam Mulia dan bagi penelitian studi lanjutan yang akan datang. Berikut ini saran yang disampaikan sebagai berikut:

1. Kompetensi karyawan PT. Antam Tbk. UBPP Logam Mulia hendaknya lebih ditingkatkan lagi, agar kemampuan yang dimiliki oleh setiap karyawan terus berkembang dan terus meningkat untuk melakukan berbagai aktivitas mental dalam 
berfikir dan memecahkan suatu masalah. Dengan cara memberikan pelatihan kepada karyawan, kompetensi yang dimiliki oleh setiap karyawan akan semakin terus berkembang, sehingga meningkatkan kinerja karyawan yang optimal.

2. Motivasi karyawan PT. Antam Tbk UBPP Logam Mulia harus terus ditingkatkan guna tercapainya kinerja karyawan yang lebih optimal, dengan adanya motivasi karyawan yang tinggi dapat mendorong semangat kerja seorang karyawan untuk dapat menyelesaikan pekerjaan dengan efektif dan efisien.

3. Perlu diadakan penelitian lebih lanjut hendaknya menambah dan menggunakan variabel-variabel lainnya yang berbeda dan memiliki potensial, instrumen pengukuran penelitian yang berbeda agar dapat diperdalam dan dikembangkan agar hasilnya dapat digeneralisasikan.

\section{DAFTAR PUSTAKA}

Bangun, Wilson. 2012. Manajemen Sumber Daya Manusia. Jakarta: Erlangga

Busro, Muhammad (2018), Teori-Teori Manajemen Sumber Daya Manusia, Jakarta: Prenada Media Group.

Desseler, Garry (2008), Human Resource Management fourth edition, New Jersey, Prentice Hall International.

Dwiyanti, Ni Kadek Ayu., Heryanda, Komang Krisna dan Susila, Gede Putu Agus Jana. 2019. Pengaruh Kompetensi Dan Motivasi Kerja Terhadap Kinerja Karyawan. Bisma: Jurnal Manajemen, Vol. 5 No. 2, Oktober 2019. Hal: 121-130 P_ISSN: 2476-8782.

Gibson, Ivancevich dan Donnely. (1996). Organisasi, Perilaku, Sturktur, Proses. Jakarta: Bina Rupa Aksara.

Hermawan, Ade dan Ainah, Noor. 2016. Peran Motivasi Dalam Meningkatkan Kinerja Pegawai Pada Dinas Sosial Dan Tenaga Kerja Kota Banjarbaru. Jurnal Ilmu-Ilmu Sosial (Socioscientia), Mareat 2016, Volume 8 Nomor 1. Hal. 65-76.

Kompri (2017), Standarisasi Kompetensi Kepala Sekolah: Pendekatan Teori untuk Praktik Profesional, Jakarta: Kencana.

Kurniasari, Rani. 2018. Pemberian Motivasi serta Dampaknya Terhadap Kinerja Karyawan Pada Perusahaan Telekomunikasi Jakarta. Jurnal Widya Cipta. Col. II, No. 1, Maret 2018. Hal. 32-39. p-ISSN: 2550-0805; e-ISSN: 2550-0791.

Pamela, A. O., \& Oloko. (2015). Effect of Motivation on Employee Performance of Commercial Banks in Kenya: A Case Study of Kenya Commercial Bank in Migori County. Journal of Human Resource Studies 5 (2).

Piandi, Didi (2018), Kinerja Guru. Sukabumi: CV Jejak.

Pradana, Saftian, I Wayan Bagia dan Gede Putu Agus Jana Susila. (2016). Pengaruh Kompetensi Interpersonal dan Motivasi Kerja terhadap Kinerja Karyawan. Denpasar Bali. Universitas Pendidikan Ganesha.

Priansa, Donni Juni. (2014). Perencanaan dan Pengembangan SDM. Bandung: Penerbit Alfabeta

Rismawati dan Mattalata (2018), Evaluasi Kinerja (Penilaian Kinerja atas Dasar Prestasi Kerja Berorientasi Kedepan, Celebes Media Perkasa.

Shaleh, Mahadin (2018), Komitmen Organisasi terhadap Kinerja Karyawan, Makasar: Aksara Timur.

Sinambela, Lijan Poltak (2018), Manajemen Sumber Daya Manusia: Membangun Tim Kerja yang Solid untuk Meningkatkan Kinerja, Jakarta: Bumi Aksara. 
Spencer, Lyle \& Signe M. Spencer. 1993. Competence at Work, Models for Superior Performance. Canada: John Wiley \& Sons, Inc.

W Parastika (2016). http://repository.unpas.ac.id/15846/4/BAB\%20II.pdf

Wibowo (2007), Manajemen Kinerja. Edisi Kelima. Depok: PT. Rajagrafindo Persada.

Yuningsih, Erni dan Ardianti. 2019. Pengaruh Kompetensi an Motivasi Terhadap Kinerja Pegawai Pada PT. XXX. Jurnal Visionida, Volume 5 Nomor 1 Juni 2019. Hal. 32-45. Undang-undang No. 13 Tahun 2003 Pasal 1(10) tentang ketenagakerjaan. 